\title{
Komunikasi Pemasaran Terhadap Brand Awareness Brand Rockickz
}

\author{
Kevin, Sinta Paramita \\ Kevin.maulany97@gmail.com,Sintap@fikom.untar.ac.id
}

Fakultas Ilmu Komunikasi Universitas Tarumanagara

\begin{abstract}
Marketing communication is a means by which companies try to inform, persuade, and remind consumers directly or indirectly about the products and brands that are sold. Marketing communication theory covers several marketing communication mixes consisting of advertising, direct marketing, sales promotion, personal selling, interactive marketing, public relations. The purpose of the marketing communication mix is to create brand awareness. This brand awareness is the ability of consumers to recognize or remember a brand, including the name, logo and also certain slogans that have been used by the brand in promoting products. During marketing communications, Rockickz carries out strategies to create brand awareness. Rockickz's strategy is in the marketing communication mix. This research methodology uses qualitative, with the case study method. Data collection is done by interview, observation and literature study.
\end{abstract}

Keywords: brand awareness, case studies, Marketing communication mix, Rockickz, qualitative

\begin{abstract}
Abstrak
Komunikasi pemasaran (marketing communication) adalah sarana dimana perusahaan berusaha menginformasikan, membujuk, dan mengingatkan konsumen secara langsung maupun tidak langsung tentang produk dan merek yang dijual. Teori komunikasi pemasaran mencangkup beberapa bauran komunikasi pemasaran terdiri dari periklanan, pemasaran langsung, promosi penjualan, penjualan personal, pemasaran interaktif, hubungan masyarakat.Tujuan dari bauran komunikasi pemasaran tersebut adalah untuk menciptakan brand awareness. Brand awareness ini merupakan kemampuan konsumen dalam mengenali atau mengingat sebuah merek, termasuk nama, logo dan juga slogan - slogan tertentu yang pernah digunakan oleh brand tersebut dalam mempromosikan produk - produk. Pada saat melakukan komunikasi pemasaran, Rockickz melakukan strategi - strategi untuk menciptakan brand awareness. Strategi yang dilakukan Rockickz terdapat dalam bauran komunikasi pemasaran. Metodologi penelitian ini menggunakan kualitatif, dengan metode studi kasus.Pengumpulan data dilakukan dengan wawancara, observasi dan studi kepustakaan.
\end{abstract}

Kata Kunci: bauran komunikasi pemasaran, brand awareness, rockickz, studi kasus, kualitatif

\section{Pendahuluan}

Gaya berbusana saat ini berkembang sangat cepat di banyak wilayah di seluruh Indonesia bahkan hampir di seluruh negara. Perkembangan ini bukan hanya dalam hal berpakaian saja seperti baju dan celana, begitu juga sepatu turut serta menjadi sesuatu yang sangat penting untuk diperhatikan dalam menunjang penampilan dalam menjalankan aktifitas sehari - hari. 
Menurut Dwi Asdono Basuki (2010) sepatu merupakan pakaian untuk kaki dan kaki merupakan anggota dari badan kita yang hidup dan bergerak, dengan bentuknya yang asimetris pada struktur dan geraknya. Gerakan pada kaki merupakan gerakan yang kompleks dari banyak tulang yang berhubungan satu dengan yang lainnya. Dengan itu dalam membuat sepatu tidak boleh asal, harus mengikuti anatomi kaki dan aturan secara ilmiah serta teknologi tertentu, sehingga hasil sepatu yang diperoleh dapat sesuai serta enak digunakan pada kaki.

Definisi dari brand awareness adalah kemampuan konsumen untuk mengenali dan mengingat kembali merek sebagai bagian dari suatu kategori produk. Bagian suatu kategori produk perlu ditekankan karena terdapat suatu hubungan yang kuat antara kategori produk dengan merek yang dilibatkan.

Rockickz adalah tempat mencuci sepatu yang namanya sudah cukup terkenal di seluruh wilayah di Indonesia. Awalnya Rockickz membuka tokonya di Tanjung Duren dan di Pasar Santa. Tidak hanya menyediakan jasa untuk mencuci sepatu, Rockickz juga menyediakan jasa mencuci tas dan topi juga. Selain jasa mencuci sepatu, Rockickz juga menyediakan unyellowing, repaint, pembetulan pada sepatu, custom sepatu. Selain itu Rockickz juga menyediakan suatu jasa pelatihan untuk unyellowing, repaint, pembetulan sepatu dan custom sepatu juga.

\section{Metode Penelitian}

Metode penelitian yang digunakan oleh penulis yaitu metode penelitian kualitatif. Menurut Moleong, penelitian kualitatif juga merupakan penelitian untuk mengerti fenomena tentang apa yang dialami oleh subjek penelitian, contohnya seperti perilaku, persepsi, aksi dan motivasi, dengan cara holistic, dengan cara menjelaskan dalam bentuk kata-kata dan juga bahasa, pada suatu konteks khusus dengan memanfaatkan berbagai macam metode alamiah (Moleong, 2009).

Sedangkan menurut Sugiyono (2010), penelitian kualitatif merupakan cara ilmiah untuk mengetahui data valid dengan tujuan yang dapat ditemukan, dikembangkan dan dibuktikan oleh pengetahuan tertentu sehingga pada gilirannya dapat digunakan untuk memahami, memecahkan, serta mengantisipasi masalah dalam bidang pendidikan.

Dalam penelitian ini, studi kasus adalah metode penelitian kualitatif yang peneliti pakai. Dalam metode studi kasus, subjek penelitian dapat meliputi individu, kelompok, lembaga maupun masyarakat. Tujuan dari studi kasus ini adalah untuk memberikan gambaran secara terperinci mengenai latar belakang, sifat serta karakter yang khas dari kasus, maupun status dari individu dan kemudian sifat-sifat khas tersebut akan dijadikan suatu hal yang bersifat umum. Studi kasus ini biasanya banyak dipakai untuk meneliti desa, kota besar, sekelompok manusia, para pemimpin dan sebagainya (Nazir, 2011).

Metode yang digunakan adalah metode studi kasus sesuai dengan yang disampaikan oleh Robert K Yin (2008). Studi kasus digunakan sebagai suatu penjelasan komprehensif yang berkaitan dengan berbagai aspek seseorang, suatu kelompok,suatu organisasi, suatu program, atau suatu situasi kemasyarakatan yang diteliti, diupayakan dan ditelaah sedalam mungkin. Studi kasus juga memiliki pengertian berkaitan dengan penelitian yang terperinci tentang seseorang atau suatu unit sosial dalam kurun waktu tertentu. 
Hal ini dilakukan supaya peneliti bisa mengumpulkan dan mendapatkan pemahaman yang mendalam mengenai individu yang diteliti, berikut masalah yang dihadapi supaya dapat terselesaikan dan membuat diri individu tersebut berkembang lebih baik.

Mengapa penulis memakai studi kasus untuk metode penelitian, karenakan penulis ingin mengetahui serta mengumpulkan informasi-informasi lebih dalam pada kasus serta masalah yang ada. Pada penulis ini, kasus dan fenomena yang diambil adalah Rockickz yang memiliki ciri khas menyediakan jasa pencucian sepatu. Nantinya untuk mengumpulkan informasi tersebut, peneliti akan menggunakan metode wawancara, observasi, dan studi kepustakaan.

Metode penelitian ini memiliki kesamaan dengan metode yang digunakan oleh Novika Anggrilita dan Sinta Paramita (2017) dalam meneliti mengenai Pariwisata di Pulau Kemaro.

\section{Hasil Penemuan dan Diskusi}

Ungkap Marcello, Rockickz ini telah melakukan pemasaran langsung, dengan cara mengikuti acara - acara sepatu yang berhubungan dengan streetwear, karena dia mempunya jasa dan produk yang berhubungan dengan fashion. Jadi untuk pemasaran langsung, biasa Rockickz mengikuti acara - acara atau bisa juga Rockickz sendiri yang membuat suatu acara yang dimana gunanya yaitu untuk menjangkau masyarakat luas.

Media yang digunakan Rockickz untuk melakukan sebuah promosi yaitu melalui media sosial yaitu Instagram kemudian marketplace juga, seperti Tokopedia, Shopee. Pada saat Rockickz melakukan promosi melalui Instagram, Rockickz melakukan paid promote, membuat Instagram bisnis.

Dalam mengiklankan Rockickz, Marcello di marketplace dan di online Rockickz ini memasang ads terus mengadakan promo, untuk yang offline biasa Rockickz mencetak flyer setelah itu di bagi - bagikan ke komplek - komplek perumahan. Sama juga pada saat ada acara - acara sepatu Rockickz mendirikan boot dan membagikan flyer juga secara halus, ungkap Marcello.

Cara Rockickz membangun Brand Awareness di mata konsumen yaitu dengan survei terlebih dahulu target dan strateginya ini mau menyerang ke umur berapa, lebih ke pria atau wanita. Kemudian Rockickz mulai mendesain logo, mendesain packaging, kemudian packaging-nya ini harus sesuai dengan target tujuan dari Rockickz ini, bila mengacu pada anak muda ya design dari packagingnya harus mempunyai desain yang milenial.

Kemudian Marcello dalam menentukan nama perusahaannya pun menggunakan merek yang mudah diingat oleh banyak orang, dan juga tidak lupa mengedepankan nama besar dari orang tuanya, sebagai gitaris dari grup band Saint Loco.

Rockickz juga mempunyai seorang Public Relation di dalamnya, gunanya untuk membangun hubungan - hubungan internal dengan client, merekalah yang menjalin komunikasinya. Contohnya bila ingin membuka boot di suatu acara sneakers, pameran - pameran, bazar - bazar atau bisa juga dalam membangun kerja sama dengan suatu perusahaan, itulah tugas seorang Public Relation dari Rockickz.

Promosi yang disampaikan ke pelanggan oleh Rockickz tidak semuanya berjalan dengan baik atau tidak semuanya berhasil. Tetapi promosi yang sangat berhasil adalah dengan acara - acara offline pada saat acara sneakers. Menurut Aldo, 
untuk masalah tolak ukur berhasil atau tidaknya promosi dari Rockickz bisa dilihat dari biaya produksi dari enam bulan pertama sama dengan jangka waktu satu tahun.

Aldo mengungkapkan bahwa yang menjadi ciri khas dari Rockickz agar banyak konsumen bila ingin mencuci sepatunya ya hanya Rockickz lah yang ada di benaknya. Yaitu dengan mengedepankan nama dari ownernya sendiri yaitu Iwan Saint Loco, walaupun pada saat ini anak dari ownernya yang bernama Marcello pun juga bekerja sebagai owner dari Rockickz. Selain itu tidak boleh dilupakan juga dalam hal memberikan pelayanan yaitu dengan sebaik mungkin, mencuci dengan detail. Dan yang paling penting itu adalah kepuasan pelanggan dari Rockickz sebut Aldo.

Menurut Alfredo Rockickz merupakan tempat jasa mencuci sepatu, pada saat itu Alfredo sedang mencari - cari tempat untuk mencuci sepatunya di media sosial yaitu Instagram. Alfredo membuka - buka instagram dan kemudian dia mendapatkan Rockickz melalui Instagram Ads, dan kebetulan toko Rockickz ini berada tidak jauh dari rumahnya, kemudian dia mencoba jasa dari Rockickz ini.

Alfredo berkata untuk masalah membangun brand awareness-nya, Rockickz ini sudah membangunnya dengan baik, melalui Instagram-nya, Rockickz menggunakan Instagram Ads, melihat dari followers-nya juga dengan ini semua menurut Alfredo sudah membangun awareness ke masyarakat juga. Karena dengan Instagram Ads ini Alfredo dapat mendapatkan informasi - informasi dari Rockickz tersebut. Dengan itu Alfredo mempercayakan jasa Rockickz ini untuk mencuci sepatunya.

Pelayanan dari Rockickz sendiri menurut Alfredo sudah cukup baik karena sebelumnya Alfredo pernah mencuci satu sepatunya di sebuah jasa tempat cuci sepatu lain, pelayanannya sama dengan Rockickz tetapi dalam penyelesaian kerja memakan waktu yang lumayan lama. Tetapi Alfredo berkata, pada saat dia mencuci sepatu di Rockickz ini, dengan harga sekian, cepat dan hasilnya memuaskan, tidak ada masalah baginya, dan ini merupakan pelayanan baik ucapnya.

Untuk pelayanan dari Rockickz sendiri Vedrian berkata bahwa pelayanannya memuaskan, walaupun harganya lebih tinggi dari kompetitor lainnya, tetapi menurutnya pelayanan dari Rockickz ini lebih cepat, lebih bersih, karena dia pernah mencuci sepatunya di tempat lain dan proses kerjanya itu memakan waktu yang cukup lama butuh 4 sampai 5 hari, tetapi di Rockickz ini hanya butuh waktu yang tidak lama yaitu 1 sampai 2 hari saja.

Selain itu Vedrian berkata, pada saat iya mencuci sepatu di tempat lain, pada saat selesai dicuci di bagian sepatunya itu masih terdapat noda kotoran yang belum hilang, tetapi saat ia mencuci sepatunya di Rockickz itu, setelah selesai dicuci sepatunya terlihat sangat bersih sampai pada bagian sol - solnya, Selain itu saat selesai dicuci sepatunya sangat harum.

Pada saat ulang tahun Rockickz yang pertama Vedrian mendapatkan promo diskon 30\% dari Rockickz, karena dia mencuci empat sepatunya, empat sepatu itu tidak semuanya milik Vedrian, tetapi ada juga milik teman - temannya yang kebetulan Vedrian ini memberi informasi kepada teman - temannya bahwa Rockickz mengadakan promo diskon $30 \%$ bila mencuci 4 sepatu di tempatnya, dan kemudian teman - temannya itu tertarik.

Vedrian mengetahui promo - promo tersebut dari Instagram, kebetulan Vedrian memfollow Instagram dari Rockickz ini, karena memang sudah sejak dulu sampai dengan saat ini Rockickz sudah sangat update di media sosialnya terutama Instagram untuk masalah promo - promonya. 
Berdasarkan tema penelitian yang dipilih oleh penulis yaitu "Komunikasi Pemasaran Terhadap Brand Awareness brand Rockickz" maka peneliti akan mengacu pada rancangan kerangka berpikir sebagai berikut:

Gambar 1. Kerangka Pemikiran

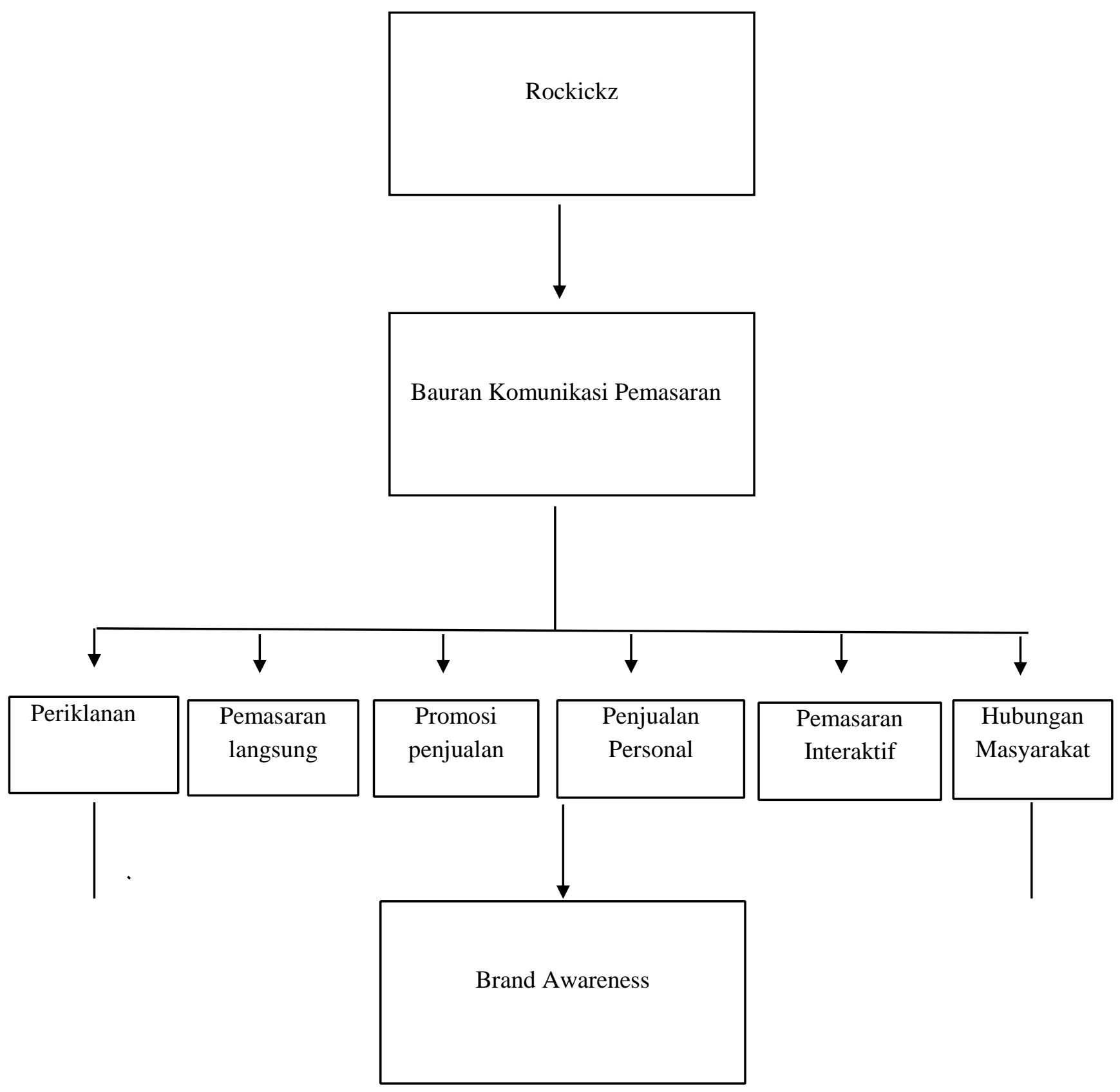

\section{Kesimpulan}

Jadi kesimpulan dari skripsi yang telah dibuat oleh penulis dengan topik yang penulis angkat mengenai komunikasi pemasaran dan brand awareness yang terjadi di tempat jasa pencucian sepatu Rockickz ini. Penulis menarik beberapa kesimpulan, yaitu bahwa Rockickz dalam menjalankan komunikasi pemasaran dan membangun brand awareness di mata konsumen sudah berjalan dengan baik atau sudah terlaksana 
dengan baik. Yang pertama dalam menjalankan komunikasi pemasarannya, Rockickz sudah menggunakan beberapa bauran dari komunikasi pemasaran seperti contohnya periklanan (advertising), pemasaran langsung (direct marketing), promosi penjualan (sales promotion), penjualan personal (personal selling), dan hubungan masyarakat (public relations).

Rockickz sangat update di media sosial instagramnya, biasa untuk promo promo, discont, give awey Rockickz menggunakan stories instagramnya untuk mengiklankan atau memberi informasi kepada semua konsumennya

Selain itu Rockickz juga telah membangun brand awareness-nya dengan cukup baik, dengan mengedepankan nama besar pemiliknya yang merupakan musikus terkenal tanah air, kemudian juga Rockickz sudah memberi atau menjadi Top of Mind nya di mata konsumen dengan perbedaan yang sangat terlihat jelas dengan tempat jasa tempat cuci sepatu lain yaitu Rockickz tidak hanya menyediakan jasa pencucian sepatu, tetapi juga bisa mencuci topi tas, repaint warna sepatu, pembenaran sepatu, custom sepatu.

Di satu sisi sepatu - sepatu, tas, topi yang biasa dicuci di Rockickz ini juga bisa menerima brand - brand ternama di dunia, seperti contohnya Gucci, Louis Vuitton, Balenciaga, Yeezy, Kenzo dan lain - lain.

\section{Ucapan Terima Kasih}

Penulis mengucapkan rasa syukur dan terima kasih atas penyelesaian penelitian ini kepada Fakultas Ilmu Komunikasi Universitas Tarumanagara dan para narasumber yang merupakan sumber dari penelitian yang sudah bersedia meluangkan waktunya serta semua pihak yang terlibat.

\section{Daftar Pustaka}

Anggrilita Novika, Paramita Sinta (2019). Upaya Dinas Pariwisata Dalam Mengembangkan Pariwisata di Pulau Kemaro. Koneksi, Vol 3, No 1(2019). Terarsip : https://journal.untar.ac.id/index.php/koneksi/article/view/2034.

Basuki, Dwi Asdono. (2010). Teknologi Sepatu. Yogyakarta: Akademi Teknologi Kulit

Moleong, Lexy J. (2009). Metode Penelitian Kualitatif. Bandung: Remaja Rosdakarya

Nazir, Moh. (2011). Metode Penelitian. Bogor : Ghalia Indonesia.

Sugiyono. (2010). Metode Penelitian Pendidikan Pendekatan Kuantitatif, kualitatif, dan $R \& D$. Bandung: Alfabeta.

Yin, Robert K. (2008).Case Study Research: Design and Methods (Applied Social Research Methods). Illinois : Sage Publications, Inc. 